\title{
原著
}

\section{走査型電子顕微鏡による豚毛歯刷子の観察 中国産豚毛について}

\author{
真 泉 平 治* 宮 沢敬 吾* 小林 義 夫* \\ 難 波 正 明* 伊藤 照子*
}

概要 : 中国産豚毛と標記された歯刷子線維を走查型電子顕微鏡を用いて観察した。

線維の尖端が理想的形態を示すものは，ナイロン線維に㧍ける場合と同じく少数であつて，種々の形 状のものが認められた。

線維の表面は低倍率では象の皮膚のような外観を呈していたが，倍率を高めると鱗状となつているこ とがわかつた。

異常なものとして，裂隙，余分な構造物の突出，尖端部が細くなつているもの，などが見られた。

\section{緒論}

走査型電子顕微鏡は，電子線の照射を受けた資 料の表面から発生する二次電子を電気的信号に変 えて, ブラウン管に資料の立体像の拡大された像 を表示する。

すなわち，赛体顕微鏡の倍率をさらに拡大させ たものであるということもできるので，われわれ は走査型電子顕微鏡を用いて歯刷子線維の観察を 行なつている。

すなわち，ナイロン歯刷子線維の観察につい て, 真泉ら”は, 深い裂隙を持つ線維が存在する こと，その裂隙が細菌によつて污染されるおそれ のあることなどについて述べており，大島 ${ }^{2}$ は線 維の尖端部の形態の 異常をいくつかの型に分類す るとともに，それらの異常が剪断操作の誤まり か, あるいはその過程で用いられる工作器具の不 備によるのではないかと述べている。

これらのナイロン線維は化学工場で大量生産さ れるために，その大きさ，線維の断面なども同一 規格につくられるはずであるが，実際にはかなり
の程度の異常が見うけられた。

豚毛はその起源から考えて，ナイロンにくらべ て変化に富むことは当然であり，加工の段階でそ の程度が一層著しくなることが，考えられる。

著者等はナイロンならびは豚毛線維について， 走査型電子顕微鏡による観察を続行しているが, このたび中国産豚毛と標記してある歯刷子線維を 観察したので，その所見について報告する。

\section{2. 観察の方法及び結果}

日本電子製走查型電子顕微鏡 JSM-UIII を用い, 加速電圧 $10 \mathrm{Kv}$ にて, 観察ならびに撮影をおこ なつた。

なお資料の蒸着には，カーボンならびに金を用 いた。

A. 断端の形態について

ナイロン線維の場合も, 理想的に剪断された線 維がきわめて少なかつたが，豚毛においても典型 的な断端を示すむのは稀であつた。

図1に示すようなものは，理想的に切られたと いつてよい数少ないもののひとつである。

* 日本歯科大学薬理学教室 (指導 真泉平治教授)

* Department of Pharmacology, Nippon Dental College (director Prof. Heiji Maizumi) 昭和 49 年 2 月 1 日受付 
ナイロン線維の場合は，理想的剪断面は平坦で あつたが，この場合は切口が平坦とはいえない。

しかしこれは材質の構造からみて，いたしかた ないことである。

図 2 , 図 3 などもやや理想に近い断面を示して いるが，その尖端部に近い線維表面に乱れが認め られ，その部をさらに詳細に観察すると，図 4 の ように表面が一部剝ぎとられたような構造を呈し ている。

異常な形態としては図 5 のようなものがあつた が，なぜこのような形になつたものか，その原因 を解明することは困難である。剪断時に複雑な操 作が，加えられたためであると思われる。

また，図6のように斜断され，しかもその断面 が極めて不整で雑然とした外観を呈し(図 7), そ の辺縁において線維を縦走する条痕に連なるもの とがある(図 8)。またこの線維の向つて左方にも 綎走する裂隙が見られる。

不整なものとしてに特に著しいものは，図 9 の ように尖端が裂けているものがあつたが，その細 部を示せば，図10, 図11のようであるが,これが 楾維に本来存在した痕によるものか, 剪断操作の みによるものか，あるいは両者の要因が重なつた ものかは，知ることができないが，おそらく要因 の重なつた結果であろう。

尖端が圧縮されたような形態の線維も見られた が,このような形のものはナイロン線維の場合に も認められた(図12)。

\section{B. 線維の表面について}

図12 と同じ線維であるが，倍率 300 倍のときに 象の皮膚のような外観を呈しているように見える （図13）が，さらに拡大してみると，熔岩状あるい は繩状を呈していることがわかつた(図14)。

これをさらに倍率を大にしてみると，図15のよ うに鱗状の外観を示すにいたつた。

このような線維表面の構造を見ると, 線条が横 走しているように見える場合が多いが，さらにこ れを倍率を大にしてみると，図16よ5に波状に見 えるが，さらに高倍率にすると，うすい層の重な りのように見える(図17)。

これを一層拡大してみると，鱗状といえるょう
に観察される(図18)。

線維の一部に異常な像の見られるものがあつた ので(図19)拡大を少し大きくしてみると，正常に 配列された鱗状の構造が乱れている部分が見られ た(図20，21)。

構造線が長軸に対して 斜走する場合もあつた が，この場合は鱗状の構造をとらず，むしろ樹皮 様を呈していた(図22，23，24)。

C．その他異常と認められるもの

線維の表面がケバ状になつているように見える 場合があつたが(図25)，これの倍率を上げてみる と, 鱗片状に近い構造で，配列に乱れのあるため であることがわかつた(図26，27)。

線維の途中に横走する傷が 見られたが(図28)， 倍率を高めると，かなり深い裂隙をつくつている ことがわかつた(図29)。

線維の太さが一様でなく，尖端に行くにしたが つて細くなるものもあつた(図30)。

線維の途中に, 余分な 構造物を突出させている ものも見られた(図 $31 ， 32 ， 33 ， 34$ )。

\section{3. 考案及び結論}

歯刷子用豚毛の高級品は昔から中国産とされて いるが，今回観察されたものは中国産と標記され ているだけで，中国産であるという確証がない。

したがつて，これが豚毛として標準品と称し得 るものかどらかは，もつとも多くの商品について 検索をかさねないとわからない。

しかし，標記されているので一応標準的豚毛之 してこれを考えることにしてみたが，尖端部の形 態は大体においてナイロン線維の場合と同じょう に多彩であつた。

ナイロン線維の尖端部の形態が意外に不整であ ることは, 当教室の大島 ${ }^{21}$, 小林 ${ }^{3)} ら の$ 検索によつ て明らかである。

しかし線維表面の条痕などは，ナイロン線維に 比較してむしろ少ないようであつた。

線維の表面が，ナイロンのように平滑でなく， 樹皮状，鱗状を呈していることは，污物が付着す る要因となることは当然考えられるが，はたして そうであるかどうかは，今後の検索を待たねばな 
らない。

\section{文献}

1）真泉平治，他：走査型電子顕微鏡による歯刷子 線維の観察(予報)．歯学，60巻，606-611, 1972.
2）大島弘子：ナイロン製歯刷子線維に見られる形 態的異常について, 走查型電子顕微鏡による観 察. 歯学, 61巻, 715-726, 1973.

3）小林義夫：走査型電子顕微鏡汇上る菌刷子線維 の観察, ナイロン歯刷子の銘柄別比較について, 菌学, $62: 178-206,1974$.

\begin{abstract}
Observation of Pig Toothbrush Bristles with the Scanning Electon Microscope: Pig bristles imported from China, Heiji Maizumi, Keigo Miyazawa, Yoshio Kobayashi, Masaaki Nanba and Teruko Ito. Pig toothbrush bristles imported from China were studied with a scanning electron microscope (model JSM U III manufactured by Japan Electron Optics Laboratory Co., Ltd.) The bristles were coated with carbon and gold, and observed under an accelerating voltage of $10 \mathrm{Kv}$. The surface of the bristles was not glassy. Under weak magnification the surface looked like bark or elephant skin, but under strong magnification the surface was seen to be scaly. Some abnormal shapes such as crevices or projections were also observed on the surface of the bristles. The form of the tips was varied, and bristles having an ideal tip were rare. This phenomenon is also seen in nylon bristles.
\end{abstract}




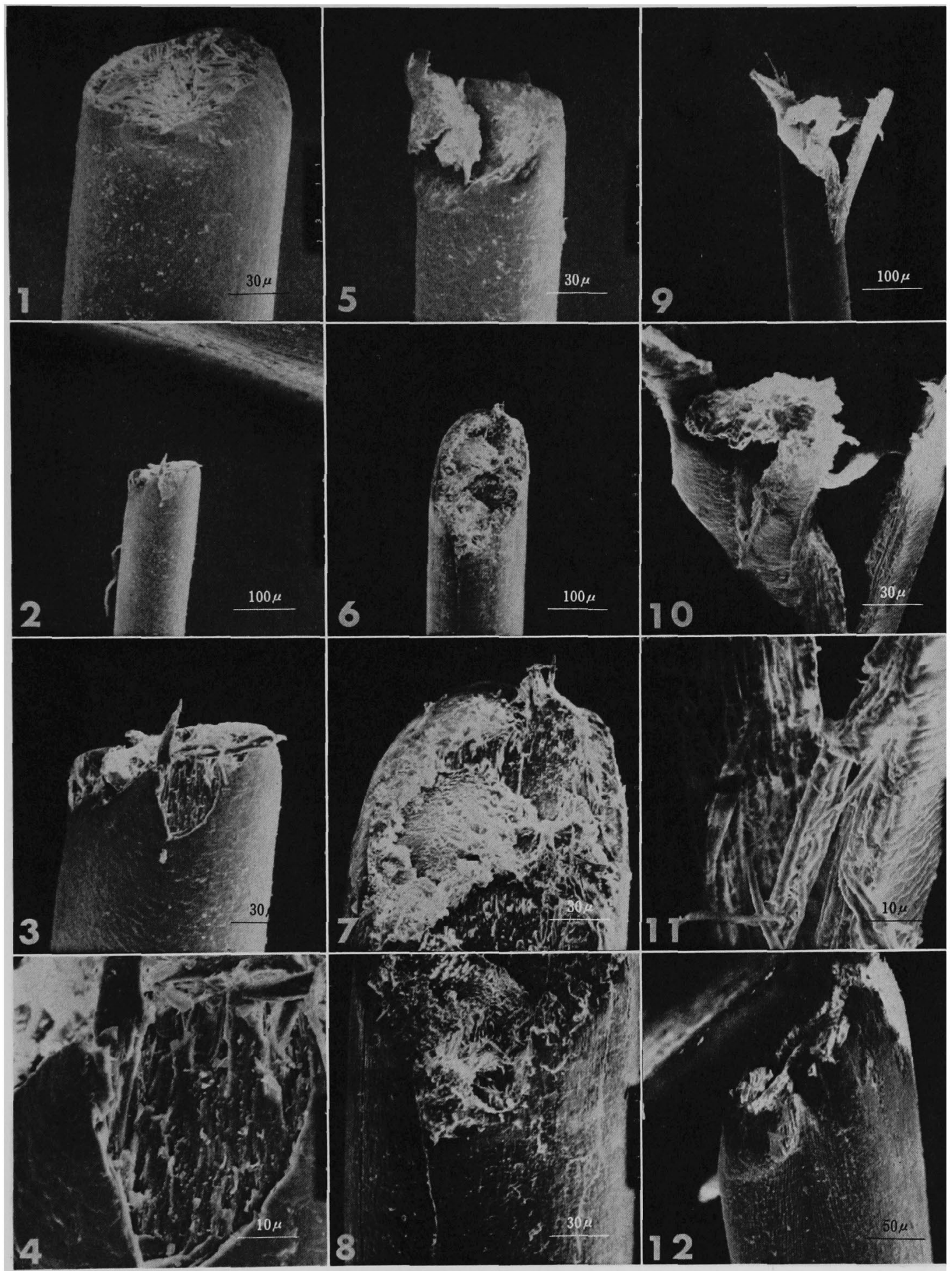




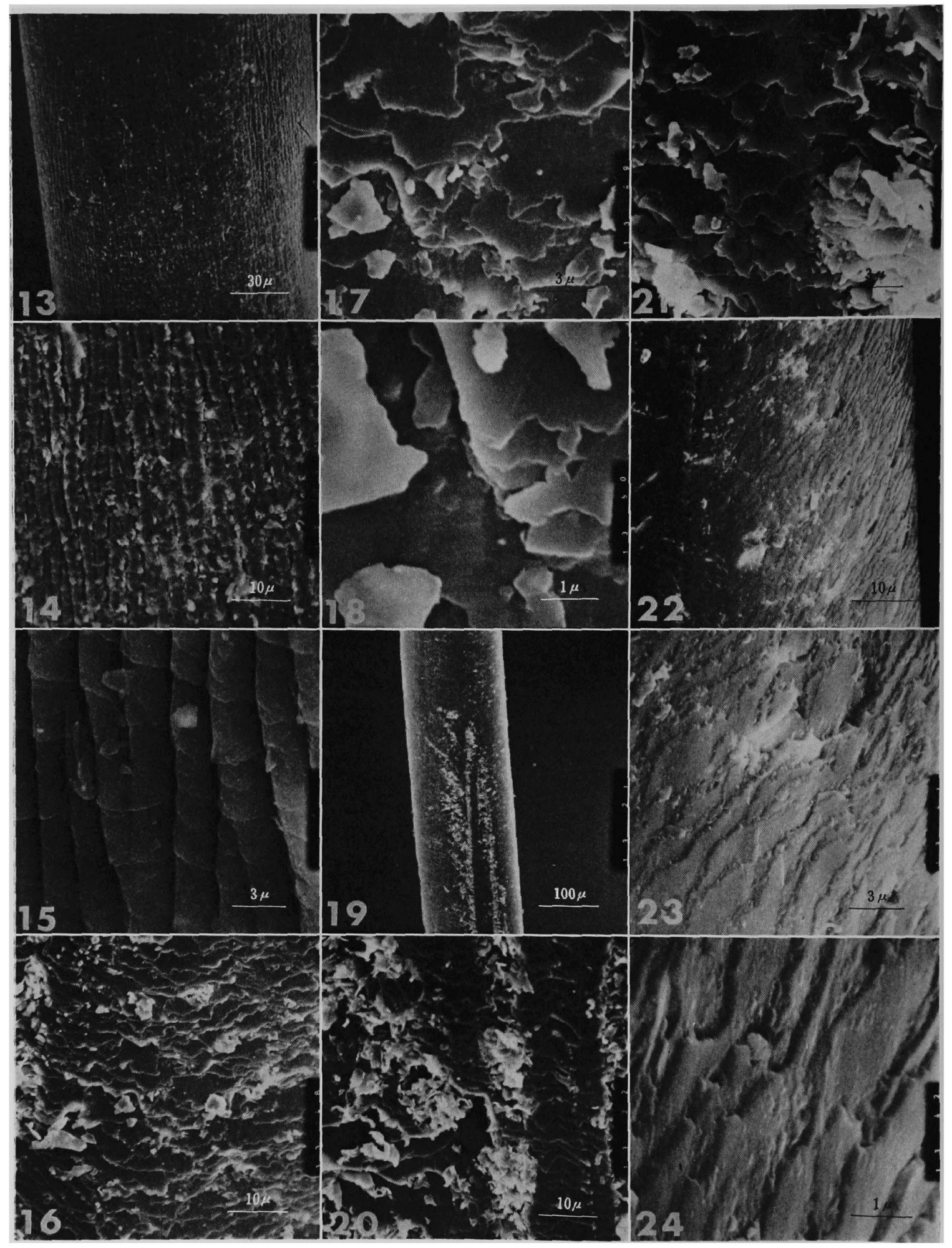




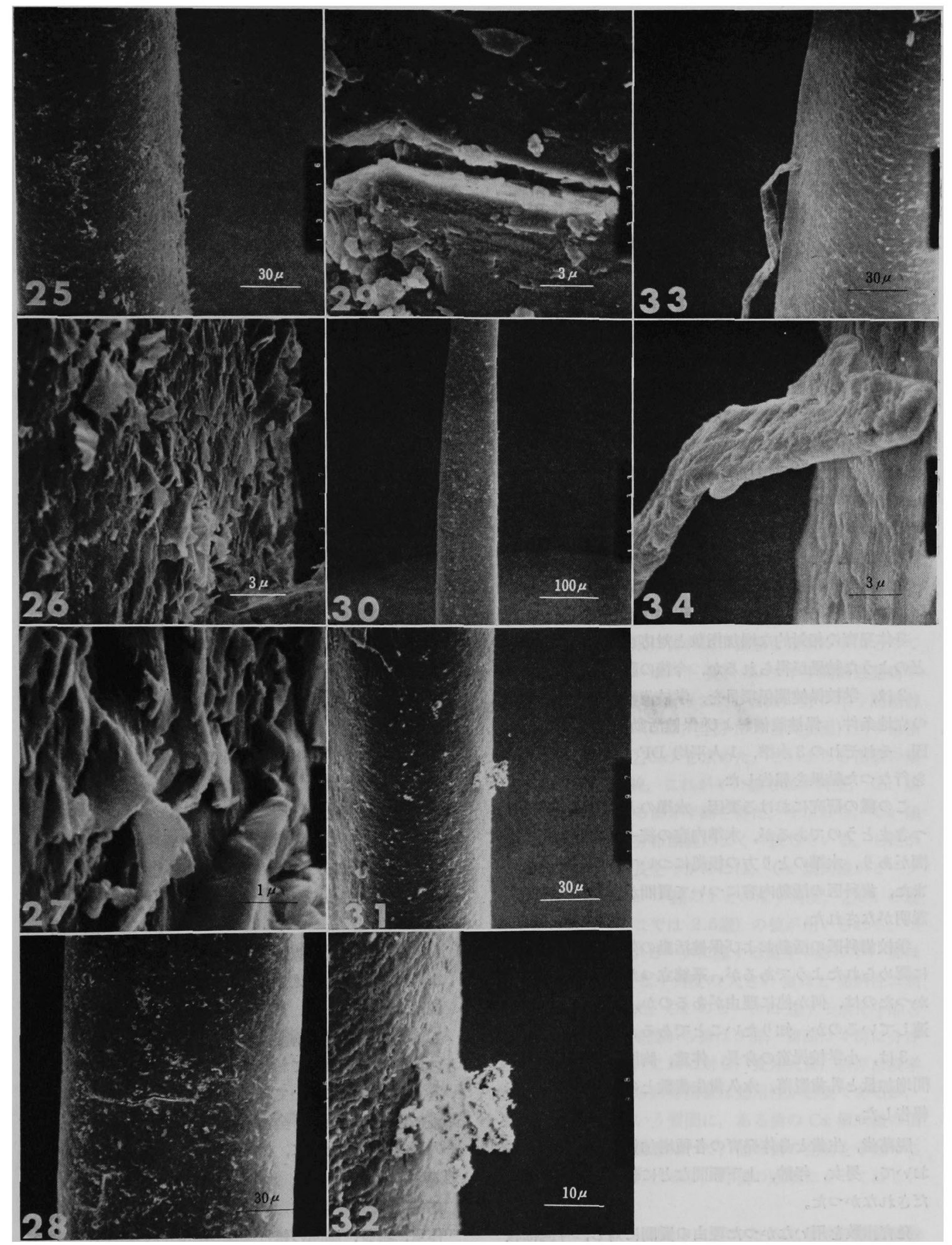

